\title{
PHYSIOLOGICAL QUALITY AND AMYLASE ENZYME EXPRESSION IN MAIZE SEEDS
}

\author{
Qualidade fisiológica e expressão das enzimas amilases em sementes de milho
}

\author{
Gustavo Evangelista Oliveira ${ }^{1}$, Renzo Garcia Von Pinho ${ }^{2}$, Thaís de Andrade ${ }^{2}$, \\ Édila Vilela de Resende Von Pinho ${ }^{2}$, Custódio Donizete dos Santos ${ }^{3}$, Adriano Delly Veiga ${ }^{2}$
}

\begin{abstract}
The physiological quality of maize seeds is affected by the genotype. Thus, the study of expression of genes associated with this characteristic is important in the genotype selection process in breeding programs. The aim of this research was to study the expression of amylase enzymes associated with physiological quality of maize seeds with different genotypes and seed sizes. We further sought to assess the expression of these enzymes in dry and soaked seeds The experiment was conducted in the experimental area and the Central Seed Laboratory of the Department of Agriculture of the Universidade Federal de Lavras. Seeds of four maize inbred lines were used, classified in two sizes. The physiological quality of the seeds was evaluated by means of germination, seedling emergence, seedling emergence speed index and accelerated aging test. Expression of the alpha amylase enzyme was evaluated by the electrophoresis technique and expression of the alpha amylase B73, alpha amylase (LOC542522) and beta amylase 5 (amyb5) genes was studied by the qRT-PCR technique in dry and soaked seeds of the inbred lines. There is differentiated expression of amylase enzymes in maize seeds of inbred lines with different levels of physiological quality. higher expression of amylase enzymes is observed in soaked maize seeds. The expression of transcripts is higher in smaller as wellas in soaked maize seeds of inbred lines.
\end{abstract}

Index terms: Zea Mays, seed quality, qRT-PCR.

\section{RESUMO}

A qualidade fisiológica de sementes de milho é influenciada pelo genótipo. Assim, o estudo da expressão de genes associados a essa característica é importante no processo de seleção de genótipos em programas de melhoramento. O objetivo neste trabalho foi estudar a expressão das enzimas amilases associadas à qualidade fisiológica de sementes de milho, de diferentes genótipos e tamanhos de sementes. Objetivou-se ainda avaliar a expressão dessas enzimas em sementes secas e embebidas. O experimento foi conduzido em área experimental e no Laboratório Central de Sementes do Departamento de Agricultura da Universidade Federal de Lavras. Foram utilizadas sementes de quatro linhagens de milho, classificadas em dois tamanhos. A qualidade fisiológica das sementes foi avaliada por meio dos testes de germinação, emergência de plântulas, índice de velocidade de emergência de plântulas e envelhecimento artificial. A expressão da enzima $\alpha$-amilase foi avaliada pela técnica de eletroforese e a expressão dos genes alpha amylase B73, alpha amylase (LOC542522) e beta amylase 5 (amyb5), foi estudada pela técnica de qRT-PCR em sementes secas e embebidas das linhagens. Há expressão diferenciada das enzimas amilases em sementes de linhagens com diferentes níveis de qualidade fisiológica. Maior expressão das enzimas amilases é observada em sementes de milho de menor tamanho e embebidas.

Termos para indexação: Zea Mays, qualidade de sementes, qRT-PCR.

(Received in october 27, 2012 and approved in december 12, 2012)

\section{INTRODUCTION}

The physiological quality of seeds is affected by the genotype, and thus selection for this characteristic must be considered in genetic breeding programs (GOMES et al., 2000; JOSÉ et al., 2004; HOECHER et al., 2006). In addition, the effect of seed size on the physiological quality of seeds has been observed in some studies (VON PINHO et al., 1995; ANDRADE et al., 1997).

In general, the selection of new cultivars considering the characteristic of seed physiological quality has not been observed in maize breeding programs. Nevertheless, after the value for cultivation and use testing for registering the cultivars, i.e., when the cultivars have already been developed, after several years of selection, one encounters cultivars that are productive but with low physiological quality, which makes placing the new cultivar on the market unviable.

Expression of genes associated with physiological quality may be assessed by means of germination and vigor analyses (COIMBRA et al., 2009; CATÃO et al., 2010)

\footnotetext{
${ }^{1}$ Universidade Federal de Lavras/UFLA - Departamento de Biologia/DBI - Cx. P. 3037 - 37200-000 - Lavras - MG - Brasil - gustavo.ufla@gmail.com ${ }^{2}$ Universidade Federal de Lavras/UFLA - Departamento de Agricultura/DAG - Lavras - MG - Brasil

${ }^{3}$ Universidade Federal de Lavras/UFLA - Departamento de Química/DQI - Lavras - MG - Brasil
} 
and furthermore by transcriptional analyses of proteins in seeds.

During the maize seed germination process, the embryo produces and secretes natural gibberellins to the endosperm. These hormones induce the development of hydrolytic enzymes in the aleurone layer, such as alpha amylase and beta amylase enzymes, which are responsible for degradation of the reserves that are found in the endosperm. Usually, alpha amylase enzymes are not present in dried seeds, being synthesized "de novo" and secreted by the aleurone layer (KIGEL; GALILI, 1995).

The alpha amylase enzyme is important in starch hydrolysis, being responsible for $90 \%$ of amylolytic activity in maize seeds. The alpha amylases constitute a family of endoamylases that catalyze the hydrolysis of $\alpha-1,4$ glycosidic linkages of starch, glycogen and other carbohydrates (FRANCO et al., 2002). This enzyme, together with the beta amylase enzyme is highly related to seed quality. For that reason, gene expression studies of these enzymes, by means of the qRT-PCR (HERNANDEZ et al., 2004; SONG et al., 2011; WANG et al., 2012) and electrophoresis (JOSÉ et al., 2005) techniques are important for knowledge of genetic behavior, thus being able to assist maize genetic breeding programs directed toward seed physiological quality.

Therefore, the aim of this research was to study the expression of amylase enzymes associated with physiological quality of maize seeds with different genotypes and seed sizes. We further sought to assess the expression of these enzymes in dry and soaked seeds.

\section{MATERIAL AND METHODS}

The experiments were conducted in the Central Seed Laboratory and experimental area of the Department of Agriculture of the Universidade Federal de Lavras (Federal University of Lavras), municipality of Lavras, MG Brazil.

Seeds from four inbred lines were discrepant in regard to seed quality according to Gomes et al. (2000), with two being of greater quality (63 and 64) and two of minor quality (43 and 54), table 1.

Table 1 - Characteristics of the inbred lines used.

\begin{tabular}{cccc}
\hline Line & Cycle & Kernel hardness & Plant Ht. \\
\hline 43 & Normal & Semiflint & Tall \\
54 & Early & Flint & Short \\
63 & Early & Flint & Medium \\
64 & Early & Flint & Medium \\
\hline
\end{tabular}

Initially, a field for multiplication of seeds of the inbred lines was installed by means of self-pollination of the plants. This field consisted of six ten-meter rows for each line, installed at a spacing of $0.8 \mathrm{~m}$. Fertilization, management and crop treatments were performed in accordance with that recommended for the crop.

The ears were collected manually when the moisture content of the seeds reached approximately $25 \%$. Husking was performed manually and drying was performed in an ear-corn dryer at a temperature of $35^{\circ} \mathrm{C}$ until the seeds reached a moisture content of $13 \%$. After drying and shelling with a manual sheller, the seeds were classified in regard to size in circular sieves and were grouped into seeds retained in the 20/64 and 22/64 pol sieves, designated as large seeds, and those retained in the $18 / 64$ and $16 / 64$ pol sieves, designated as small seeds.

After seed classification, a germination test was performed to verify initial quality of the seeds. Through the results, it could be seen that the seeds from all the inbred lines showed high physiological quality, for the experimental conditions during their production phase were favorable. For selection of discrepant genotypes, just as for physiological quality of the seeds, it was necessary to submit them to accelerated aging. For that reason, the seeds were treated with the fungicide 5,6 - dihydro-2methyl-1,4-oxathi-ine-3-carboxanilide (200 g/L) and tetramethylthiuram disulfide $200 \mathrm{~g} / \mathrm{L}$ at a dose of $250 \mathrm{ml}$ for each $100 \mathrm{Kg}$ of seeds. The method used for aging was transparent plastic boxes $(11 \times 11 \times 3,5 \mathrm{~cm})$, where the seeds were distributed on a screen suspended in the inside of a box containing $40 \mathrm{~mL}$ of water, where they remained incubated for 96 hours at a temperature of $41^{\circ} \mathrm{C}$ (VIEIRA; CARVALHO, 1994). The aged seeds were homogenized and dried in a shaded area at ambient temperature until reaching initial water content of $13 \%$.

Assessment of the physiological quality of the seeds of the four inbred lines was initially performed by means of germination counting in three, five and seven days (BRASIL, 2009), seedling emergence and emergence speed index was performed in plastic box with two parts of soil and one part of sand (EDMOND; DRAPALA, 1958) and accelerated aging test, these tests are according to Gomes et al. (2000).

For analysis of alpha amylase enzyme expression by means of the electrophoresis technique, small and large seeds of the four inbred lines soaked in germitest paper for 70 hours were used. After this period, the embryonic axes were removed and the endosperms were cold ground in liquid nitrogen (ROOD; LARSEN, 1988) and stored in a 
freezer at $-81^{\circ} \mathrm{C}$. Another sample of dry seeds was cold ground in liquid nitrogen and stored in a freezer at $-81^{\circ} \mathrm{C}$ up to the time of analysis. Extraction and revelation of the alpha amylase enzyme was performed according to Alfenas (1998).

In addition, analysis of beta amylase and alpha amylase expression was performed by means of the qRTPCR technique. That way, RNA extraction was carried out from seeds of inbred lines with high and low physiological quality and two sizes, which were crushed in liquid nitrogen and with addition of the reagent Pure Link RNA Plant ${ }^{\circledR}$ (Invitrogen), according to manufacturer specifications. Integrity of the RNA was verified in $1 \%$ agarose gel and viewed after staining with ethydium bromide. RNA quantification was performed in a sprectrophotometer, using wavelengths from 260 and $280 \mathrm{~nm}$.

After nucleic acid extractions, the samples were treated with DNAse Free to avoid any contamination with DNA. Therefore, DNase DNA Free (Ambion) was used and protocol carried out according to manufacturer recommendations. To prove efficiency of decontamination, a conventional PCR reaction was made with all the samples, proving the non-amplification of the DNA. In this reaction, a DNA sample of maize seeds and the primers of the endogenous controls Ubiquitin and Alcohol Dehydrogenase (ADH) were used as positive control. The amplifications were assessed in $1.5 \%$ agarose gel stained with ethydium bromide.

After the RNA extraction and purification process, synthesis of cDNA was carried out. For this purpose the
High Capacity cDNA Reverse Transcription cDNA $^{\circledR}$ kit from Applied Biosystems was used, following the protocol recommended by the manufacturer.

For analysis of gene expression by the qRT-PCR technique, the primers used were designed with the assistance of the software Primer Express 3.0 (Applied Biosystems) after a search of the gene sequence at National Center for Biotechnology Information (NATIONAL CENTERFOR BIOTECHNOLOGYINFORMATION-NCBI, 2012), table 2. Ubiquitin and ADH genes (LIVAK; SCMITTGEN, 2001; SCHOLDBERG et al., 2009) were used as endogenous controls.

The equipment ABI PRISM 7500 Real-Time PCR (Applied Biosystems) was used for analysis of quantitative gene expression by qRT-PCR using the detection system SYBR Green and cDNA was obtained from RNA extracted from seeds. Thermal conditions of the reaction were 2 minutes at $50^{\circ} \mathrm{C}, 10$ minutes at $95^{\circ} \mathrm{C}$, followed by 40 cycles of 15 seconds at $95^{\circ} \mathrm{C}$ and 1 minute at $60^{\circ} \mathrm{C}$, and finalized with 15 seconds at $95^{\circ} \mathrm{C}$. The data were collected and stored in the program 7500 software (version 2.0.1). For each reaction, $1.0 \mu \mathrm{L}$ of cDNA diluted $1: 5,0.2 \mu \mathrm{L}$ of each primer and 5.0 $\mu \mathrm{L}$ of master mix SYBR green UDG with ROX (Invitrogen) were used for a final volume of $10.0 \mu \mathrm{L} /$ sample. The negative controls and melting curves were included in all the analyses.

Three technical replications were used for each gene under study, with the results normalized using the Threshold Cycle (CT) obtained by expression of the reference genes ubiquitin and $\mathrm{ADH}$.

Table 2 - Primers used in the analysis of $q R T-P C R$ in seeds of different maize inbred lines.

\begin{tabular}{llc}
\hline Gene & & Sequence 5'---------3' \\
\hline \multirow{2}{*}{ Alpha amylase B73 } & $\mathrm{F}$ & CCGGCTCCACGCAGAAC \\
& $\mathrm{R}$ & TATAGGCGTAGCCCTGCATGA \\
Alpha amylase (LOC542522) & $\mathrm{F}$ & TGCAGCCTCCTAGTGCTTGTAC \\
& $\mathrm{R}$ & TGGAAGAGGACCTGGGATTG \\
Isoamylase mRNA clone 353244 & $\mathrm{F}$ & CATGAAGGACGAAACCAAAGG \\
Beta amylase5 (amyb5) & $\mathrm{R}$ & TCTGGAAGCCCAACAACCA \\
& $\mathrm{F}$ & GAACGCGCTAGCCAACTATGT \\
Ubiquitin & $\mathrm{R}$ & CGAACGTGTTGTCGACAGTGA \\
& $\mathrm{F}$ & AAGGCCAAGATCCAGGACAA \\
Alcohol Dehydrogenase (ADH) & $\mathrm{R}$ & TTGCTTTCCAGCGAAGATGA \\
& $\mathrm{F}$ & AGGACGCTGAGTTAAGACC \\
\hline
\end{tabular}

(F) sequence of the forward primer and $(\mathrm{R})$ sequence of the reverse primer. 
CT was determined by the number of cycles in which the fluorescence generated within a reaction crosses the baseline (threshold). The CT comparative method was used. For that purpose, a validation experiment was carried out in advance to prove that the amplification efficiencies of the target genes and references are similar and very near $100 \%$ (TYAGI; BRATU; KRAMER, 1998). The standard curves for the genes under study were generated from the following dilutions: 1:5, 1:25, 1:125, 1:625 and 1:3125. This procedure also allowed definition of the best dilution of cDNA used in each reaction, which was 1:5.

The samples of least expression for each gene were used as calibration samples and the method used to measure relative expression was the relative standard curve method, described in the manual of the device (AppliedBiosystems). For quantification of gene expression by the PCR technique in real time, the values obtained corresponding to the mRNA levels of the samples were compared in relation to the values of the control mRNA levels. After obtaining crude data, they were analyzed by means of the 7500 software SDS program (version 2.0.1). To calculate the level of expression of genes of interest, the following were considered: $\mathrm{Ct}$ (exponential increase of the $\mathrm{PCR}$ product) of the target gene and endogenous control, $\Delta \mathrm{Ct}=\mathrm{Ct}$ (sample) $-\mathrm{Ct}$ (endogenous control) and the $\Delta \Delta \mathrm{Ct}=\Delta \mathrm{Ct}$ (sample) - $\Delta \mathrm{Ct}$ (calibrator). Then the level of expression was calculated by the formula: $R Q=2^{-\Delta \Delta C t}$.

For analysis of results of the tests used for assessment of physiological quality, a fully randomized design was used in a $4 \times 2$ factorial arrangement, with four inbred lines and two seed sizes, with four replications. Comparison of the means of the treatments for the tests was carried out by the Scott \& Knott test at the 5\% probability level. Analyses were performed on the statistical program R 2.14.1 (2011).

\section{RESULTS AND DISCUSSION}

By the results of analysis of variance of the data obtained in the germination, accelerated aging test, emergence and emergence speed index tests (Table 3), a highly significant $(\mathrm{P} \leq 0.01)$ effect was observed for the interaction between the size $\mathrm{x}$ inbred line factors and for each isolated factor, with the exception of the emergence speed index, where the size factor was not significant.

The mean values of the data obtained are presented in Tables 4 and 5, together with their groupings by the Scott \& Knott test at the 5\% probability level.

In the germination test, assessments were performed at three, five and seven days. Lower values of germination at three and five days, regardless of the seed size, were observed in seeds of the inbred lines (43 and 54 ), defined by Gomes et al. (2000) as being of low quality (Table 4).

In general, in the seeds of inbred line 64, greater mean values of germination were observed in all assessment periods, regardless of size. In small seeds, inferior mean germination values were also observed at seven and five days for inbred lines 54 and 63.

Through the results of the accelerated aging test (Table 5), less vigor was observed in small seeds of inbred lines 43 and 54, and large seeds of inbred line 43. These results are in agreement with those obtained by Gomes et al. (2000), who worked with these same inbred lines and observed that inbred lines 43 and 54 were less vigorous than the others. Less vigor was also observed in small seeds of inbred lines 54 and 64, respectively.

In regard to seedling emergence (Table 5), it was observed that the large seeds of the four inbred lines did not differ among themselves. For the small seeds, lower values were observed in seeds from inbred lines 43 and 63.

Table 3 - Summary of analysis of variance of the data obtained in the germination, accelerated aging test (AG), emergence speed index (ESI) and seedling emergence tests of maize seeds of different inbred lines and two sizes (small and large).

\begin{tabular}{|c|c|c|c|c|c|c|c|}
\hline \multirow{3}{*}{ Factors } & \multirow{3}{*}{ GL } & \multicolumn{6}{|c|}{$\mathrm{QM}$} \\
\hline & & \multicolumn{3}{|c|}{ (\%) Germination } & \multirow{2}{*}{$\mathrm{AG}$} & \multirow{2}{*}{ ESI } & \multirow{2}{*}{ (\%) Emergence } \\
\hline & & 3 days & 5 days & 7 days & & & \\
\hline Inbred line & 3 & 9319* & $17225^{*}$ & $16.45^{*}$ & $156.8^{*}$ & $0.14924 *$ & $18.8^{*}$ \\
\hline Size & 1 & $496.1^{*}$ & $136.1 *$ & $28.12 *$ & $98^{*}$ & 0.00001 & $84.5^{*}$ \\
\hline Inbred line*Size & 3 & $132.8^{*}$ & $46.1^{*}$ & $43.45^{*}$ & $48.3^{*}$ & $0.06144 *$ & $19.5^{*}$ \\
\hline Residue & 24 & 17.4 & 12.6 & 3.10 & 6.1 & 0.00108 & 4.7 \\
\hline $\mathrm{CV}(\%)$ & & 13.21 & 6.66 & 1.85 & 2.75 & 2.87 & 2.23 \\
\hline
\end{tabular}

*Significant at the $1 \%$ probability level by the $\mathrm{F}$ test. 
Table 4 - Mean results (\%) of the germination test of seeds of maize inbred lines of two sizes, small (S) and large (L), assessed in different periods.

\begin{tabular}{crrrrrc}
\hline \multirow{2}{*}{ Inbred line } & \multicolumn{2}{c}{3 days } & \multicolumn{2}{c}{5 days } & \multicolumn{2}{c}{7 days } \\
\cline { 2 - 7 } & \multicolumn{1}{c}{$\mathrm{S}$} & $\mathrm{L}$ & $\mathrm{S}$ & $\mathrm{L}$ & $\mathrm{S}$ & $\mathrm{L}$ \\
\hline 43 & $2 \mathrm{C} \mathrm{a}$ & $3 \mathrm{C} \mathrm{a}$ & $9 \mathrm{C} \mathrm{a}$ & $10 \mathrm{C} \mathrm{a}$ & $96 \mathrm{~B} \mathrm{a}$ & $94 \mathrm{~B} \mathrm{a}$ \\
54 & $2 \mathrm{C} \mathrm{a}$ & $3 \mathrm{C} \mathrm{a}$ & $14 \mathrm{C} \mathrm{b}$ & $20 \mathrm{~B} \mathrm{a}$ & $91 \mathrm{C} \mathrm{b}$ & $99 \mathrm{~A} \mathrm{a}$ \\
63 & $47 \mathrm{~B} \mathrm{~b}$ & $64 \mathrm{~B} \mathrm{a}$ & $86 \mathrm{~B} \mathrm{~b}$ & $96 \mathrm{~A} \mathrm{a}$ & $95 \mathrm{~B} \mathrm{~b}$ & $98 \mathrm{~A} \mathrm{a}$ \\
64 & $60 \mathrm{~A} \mathrm{~b}$ & $73 \mathrm{~A} \mathrm{a}$ & $96 \mathrm{~A} \mathrm{a}$ & $96 \mathrm{~A} \mathrm{a}$ & $99 \mathrm{~A} \mathrm{a}$ & $97 \mathrm{~A} \mathrm{a}$ \\
\hline
\end{tabular}

* Mean values followed by the same capital letter in the column and small letter in the line, for each assessment period, belong to the same grouping by the Scott \& Knott test at $5 \%$ probability.

Table 5 - Mean results of vigor obtained by the accelerated aging test (AG), seedling emergence and emergence speed index (ESI) tests of seeds of maize inbred lines and small (S) and large (L) size.

\begin{tabular}{crrrrrc}
\hline \multirow{2}{*}{ Inbred line } & \multicolumn{2}{c}{$\mathrm{AG}(\%)$} & \multicolumn{2}{c}{ Emergence $(\%)$} & \multicolumn{2}{c}{ ESI } \\
\cline { 2 - 6 } & $\mathrm{S}$ & $\mathrm{L}$ & $\mathrm{S}$ & \multicolumn{1}{c}{$\mathrm{S}$} & $\mathrm{L}$ \\
\hline 43 & $86 \mathrm{~B} \mathrm{a}$ & $83 \mathrm{~B} \mathrm{a}$ & $93 \mathrm{~B} \mathrm{~b}$ & $98 \mathrm{~A} \mathrm{a}$ & $3.882 \mathrm{C} \mathrm{b}$ & $3.712 \mathrm{~B} \mathrm{a}$ \\
54 & $83 \mathrm{~B} \mathrm{~b}$ & $93 \mathrm{~A} \mathrm{a}$ & $97 \mathrm{~A} \mathrm{a}$ & $99 \mathrm{~A} \mathrm{a}$ & $3.458 \mathrm{~A} \mathrm{a}$ & $3.469 \mathrm{~A} \mathrm{a}$ \\
63 & $92 \mathrm{~A} \mathrm{a}$ & $95 \mathrm{~A} \mathrm{a}$ & $93 \mathrm{~B} \mathrm{~b}$ & $100 \mathrm{~A} \mathrm{a}$ & $3.657 \mathrm{~B} \mathrm{a}$ & $3.575 \mathrm{~A} \mathrm{a}$ \\
64 & $91 \mathrm{~A} \mathrm{~b}$ & $95 \mathrm{~A} \mathrm{a}$ & $99 \mathrm{~A} \mathrm{a}$ & $98 \mathrm{~A} \mathrm{a}$ & $3.491 \mathrm{~A} \mathrm{a}$ & $3.729 \mathrm{~B} \mathrm{~b}$ \\
\hline
\end{tabular}

* Mean values followed by the same capital letter in the column and small letter in the line, for each test, belong to the same grouping by the Scott \& Knott test at $5 \%$ probability.

The results of the emergence speed index obtained by the formula proposed by Edmond and Drapala (1958) supplies the mean number of days to emergence. It may be observed from the results of Table 5 that for the large seeds, the best indexes were for inbred lines 54 and 63, while for small seeds, the best indexes were observed in seeds of inbred lines 54 and 64.

In general, in the results of tests used for assessment of physiological quality, lower germination and vigor values were observed in seeds of inbred line 43 , and better physiological quality in seeds of inbred line 64. It should be noted that depending on the test used, there are some inversions of behavior. According to Gomes et al. (2000), José et al. (2004) and Souza et al. (2008), the physiological quality of maize seeds is controlled by various genes and thus, the conditions during the seed production process may affect the behavior of the inbred line, which requires assessment of quality of seeds produced under different climatic conditions.

The climatic conditions during the seed production process were favorable to the physiological quality of the seeds. For that reason, there was the necessity of submitting the seeds to the accelerating aging before the assessment of physiological quality by the germination and vigor tests. The statistically significant differences observed between nearby germination and vigor values resulting from low values of the coefficient of variation should furthermore be noted (Table 3).

There was a tendency for the large seeds to present mean values greater than the small seeds, just as reported by Carvalho and Nakagawa (2000), who observed greater germination of larger seeds as opposed to the smaller. Nevertheless, there is no consistency of results in the different genotypes, which corroborates the results of Andrade et al. (1997) and Nafziguer (1992). These authors furthermore concluded that the size and format of the maize seeds did not present any significant effect on grain yield.

In figure 1 are presented the isoenzyme patterns of alpha amylase in large and small seeds of maize lines submitted to soaking. Greatest expression of the enzyme was observed in seeds of inbred line 63, and the least expression in those of inbred line 43. The alpha amylase enzyme is important in starch hydrolysis, being responsible for $90 \%$ of amylolytic activity in maize seeds (FRANCO et al., 2002). Thus, seeds of genotypes with greater expression of these enzymes have greater ease in making carbohydrates available to the embryo, resulting in greater germination speed and vigor. 


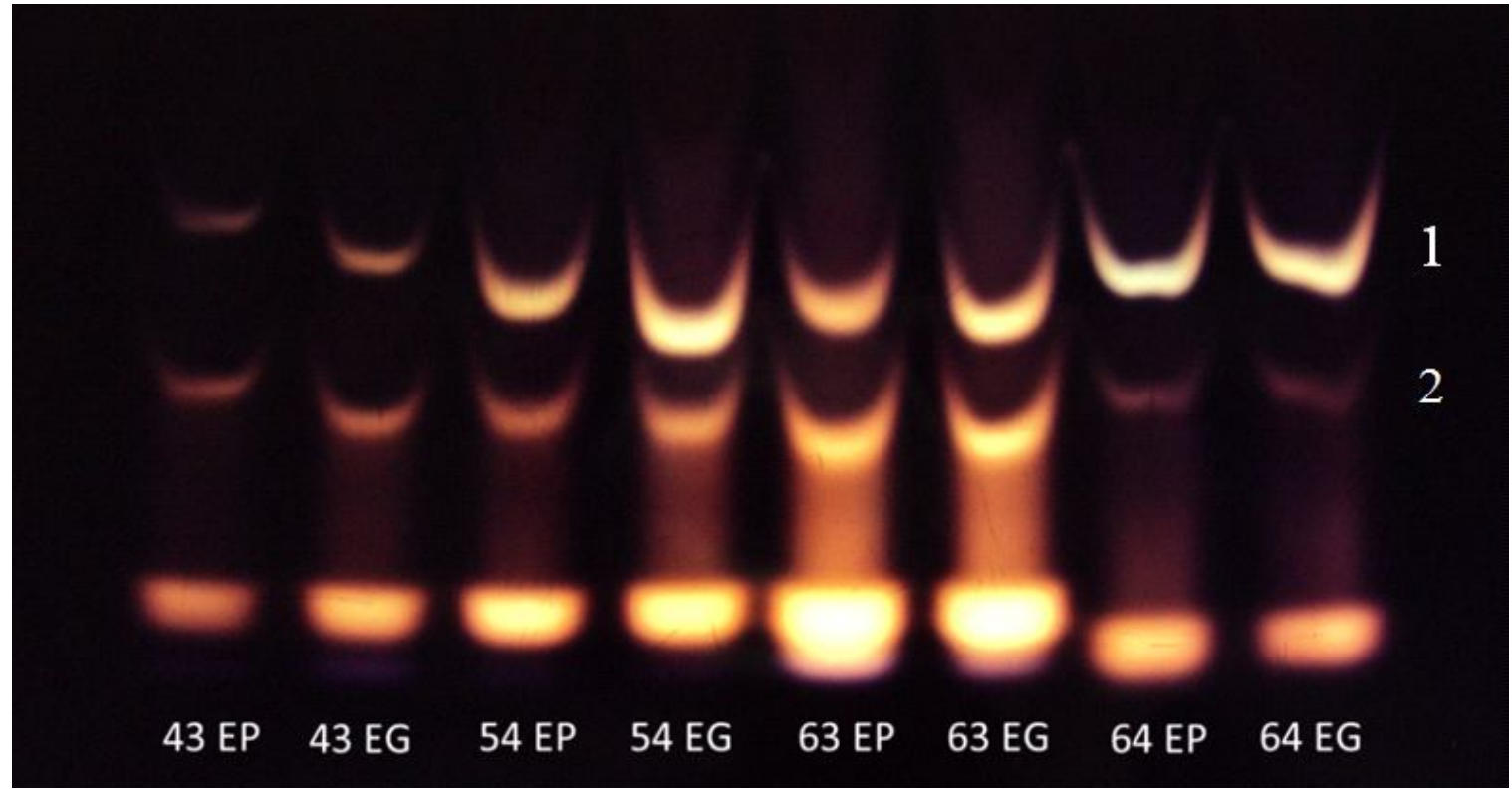

Figure 1 - Isoenzyme patterns of alpha amylase of soaked maize seeds (E) of different lines and sizes, small (P) and large (G), shown for $\alpha$-amylase ( 1 and 2 correspond to specific isoforms).

In dry seeds, the expression of alpha amylase was not observed by the electrophoresis technique. This is due to the low activity of this enzyme in the dry seeds, with its synthesis by the aleurone layer "de novo" being necessary (KIGEL; GALILI, 1995).

Starch degradation, the main reserve source in most of the seeds of tilled plants, is essential in germination of these seeds (YAMASAKI, 2003). By the results (Figures 1 and 2), it may be observed that the activity of the amylases increases considerably during the soaking process. The same was observed by Sana et al. (2009) working with turnip and wheat seeds.

In relation to seed size, the greatest expression of this enzyme was observed in large seeds of inbred line 54 (Figure 1). In these seeds, greater germination values at 5 and 7 days and greater vigor by the accelerated aging test were observed (Tables 4 and 5).

By the isoenzyme patterns obtained by means of the electrophoresis technique, greater expression of the alpha amylase enzyme in seeds of inbred line 63, regardless of the size, was also observed (Figure 1).

In regard to lower expression of the gene in dry seeds, it is observed that most of the amylase enzymes involved in germination of maize seeds are synthesized "de novo", with the need for soaking. According to Lovegrove and Hooley (2000), Nakajima et al. (2006) and
Xie et al. (2007), after soaking, synthesis of gibberellin occurs, which is secreted in the aleurone layer, where it activates alpha amylase synthesis.

In figure 2A, greater expression of the AmyB73 gene is observed in soaked seeds of inbred line 64 . Expression of this gene was not observed in dry seeds in any of the inbred lines, and in this situation there is "de novo" synthesis of the enzyme after soaking of the seeds (KIGEL; GALILI, 1995). This behavior was also observed for the alpha amylase gene (LOC542522), with greater expression in soaked seeds of inbred line 63 (Figure 2B).

It may be inferred that the AmyB73 and alpha amylase (LOC542522) genes are associated with the physiological quality of seeds of the inbred lines studied. For lines 64 and 63 classified as having seeds of greater physiological quality, the greatest values of expression of the AmyB73 and alpha amylase (LOC542522) genes were observed, respectively. By means of germination and vigor tests, lower physiological quality was observed in seeds of inbred line 43. For these two genes in this inbred line, the lowest expression was observed. It should be noted that in this inbred line there was expression of the alpha amylase (LOC542522) gene only in the large and soaked seeds.

In relation to the AmyBeta5 gene (Figure 2C), its expression was observed only in the soaked seeds. 
Moreover, greater expression was observed in small soaked seeds. The beta amylase enzyme is synthesized during seed development and its release and activation occurs during germination, being accompanied by the accumulation of its isoforms (SOPANEN; LAURIÈRE, 1989). The gene in reference is related to synthesis of beta amylase in the literature. Nevertheless, its expression was not observed in dry seeds.

Comparing the results of the expression observed by the qRT-PCR and electrophoresis techniques, specific isoforms which may be associated with the genes under study are verified in the alpha amylase zymogram (Figure 1). It is inferred that the AmyB73 gene (Figure 2A) is associated with isoform 1 of alpha amylase and the alpha amylase (LOC542522) gene (Figure 2B) is associated with isoform 2 of alpha amylase.

Furthermore, in relation to the zymogram presented in figure 1, greater activity of the alpha amylase enzyme is observed for inbred line 63, and upon comparing these results with the expression assessed by the qRT-PCR technique, greater expression of the alpha amylase (LOC542522) and AmyBeta5 genes is observed (Figure 2).
Thus, upon assessing amylase enzyme expression by means of the electrophoresis and qRT-PCR techniques and by the results of tests used for assessment of physiological quality, it is observed that inbred line 43 presents lower physiological quality, which could compromise its use in hybrid composition, principally as a female parent. Thus, by means of these analyses, there was significant expression of genes associated with amylase enzymes and with physiological quality of the seeds.

Analysis of the alpha amylase enzyme expression profile by means of the electrophoresis technique may be used to assist selection of genotypes in breeding programs. That way, it is possible to eliminate genotypes with minor seed quality in the initial phases of the program.

It is important to emphasize that various genes in addition to the amylases may be involved in control of the seed physiological quality trait. For example, genes directly related to plant respiration may be cited. Therefore, it is suggested that new studies be carried out seeking to involve a greater number of multigene families and genes.

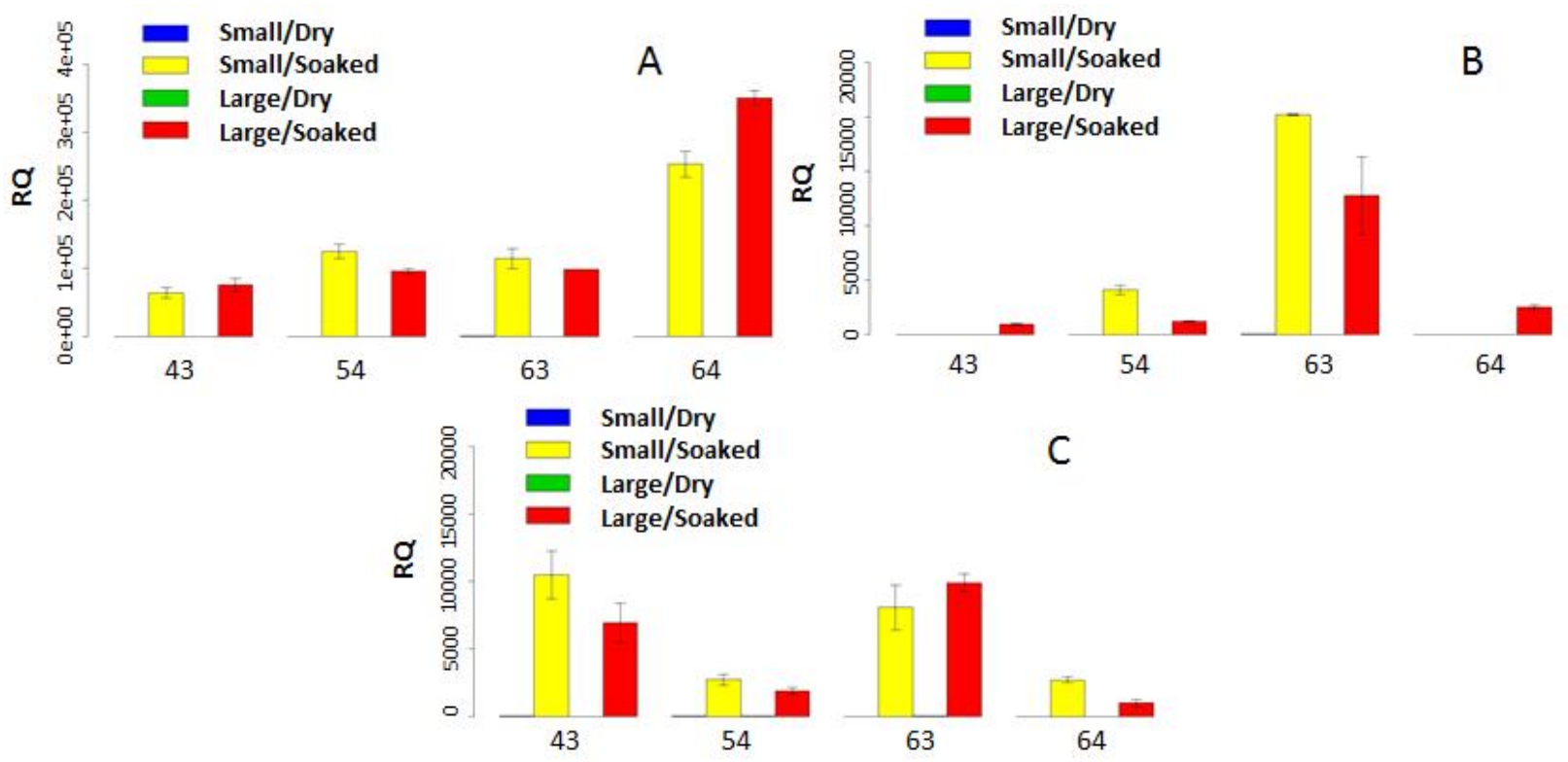

Figure 2 - Relative quantitative expression profile of the gene: A- alpha amylase B73 (AmyB73); B - alpha amylase (LOC542522); C - beta amylase5 (AmyBeta5), in small and large, dry and soaked seeds of maize inbred lines. 


\section{CONCLUSIONS}

There is differentiated expression of amylase enzymes in maize seeds of inbred lines with different levels of physiological quality.

Higher expression of amylase enzymes is observed in soaked maize seeds.

The expression of transcripts is higher in smaller as well as in soaked maize seeds of inbred lines.

\section{ACKNOWLEDGEMENTS}

To the National Council of Scientific and Technological Development (Conselho Nacional de Desenvolvimento Científico e Tecnológico - CNPq), CAPES and the Research Support Foundation of the State of Minas Gerais (Fundação de Amparo à Pesquisa do Estado de Minas Gerais - FAPEMIG) for financial support.

\section{REFERENCES}

ALFENAS, A. C. Eletroforese de isoenzimas e proteínas afins: fundamentos e aplicações em plantas e microorganismos. Viçosa, MG: UFV, 1998. 574 p.

ANDRADE, R. V. et al. Efeito da forma e do tamanho da semente no desempenho no campo de dois genótipos de milho. Revista Brasileira de Sementes, Curitiba, v.19, n.1, p 62-65, 1997.

BRASIL. Ministério da Agricultura, Pecuária e Abastecimento. Regras para análise de sementes. Brasília, 2009.399p.

CARVALHO, N. M.; NAKAGAWA, J. Sementes: ciência, tecnologia e produção. 4. ed. Jaboticabal: FUNEP, 2000. $588 \mathrm{p}$.

CATÃO, H. C. R. M. et al. Qualidade física, fisiológica e sanitária de sementes de milho crioulo produzidas no norte de Minas Gerais. Ciência Rural, Santa Maria, v.40, n.10, p.2060-2066, 2010.

COIMBRA, R. A. et al. Teste de vigor utilizados na avaliação da qualidade fisiológica de lotes de sementes de milho-doce (sh2). Ciência Rural, Santa Maria, v.39, n.9, p.2402-2408, 2009.

EDMOND, J. B.; DRAPALA, W. J. The effects of temperature, sand and soil, and acetone on germination of okra seed. American Society of Horticutural Science, Alexandria, n.71, p.428-434, 1958.
FRANCO, O. L. et al. Plant $\alpha$-amylase inhibitors and their interaction with insect a-amylases. European Journal of Biochemistry, Berlin, v.269, p.397-412, 2002.

GOMES, M. S. et al. Efeito da heterose na qualidade fisiológica de sementes de milho. Revista Brasileira de Sementes, Brasília, v.22, n.1, p.7-17, 2000.

HERNANDEZ, M. et al. Development and comparison of four real-time polymerase chain reaction systems for specific detection and quantification of Zea mays.

Journal of Agricultural and Food Chemistry, Easton, v.52, p.4632-4637, 2004.

HOECKER, N. et al. Manifestation of heterosis during early maize (Zea mays $L$.) root development. Theoretical and Applied Genetics, Berlin, v.112, n.3, p.421-429, 2006.

JOSÉ, S. C. B. R. et al. Controle genético da tolerância à alta temperatura de secagem em sementes de milho.

Revista Brasileira de Milho e Sorgo, Sete Lagoas, v.3, n.3, p. 414-428, set./dez. 2004.

JOSÉ, S. C. B. R. et al. Padrão eletroforético de proteínas resistentes ao calor em sementes de milho. Pesquisa Agropecuária Brasileira, Brasília, v.40 n.2, p.115-121, 2005.

KIGEL, J.; GALILI, G Seed development and germination. New York: M. Dekker, 1995. 853 p.

LIVAK, K. J.; SCMITTGEN, T. D. Analysis of relative gene expression data using real-time quantitative PCR

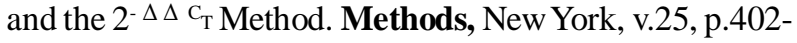
$408,2001$.

LOVEGROVE, A.; HOOLEY, R. Gibberellin and abscisic acid signalling in aleurone. Trends in Plant Science, Oxford, v.5, p.102-110, 2000.

NAFZIGUER, E. D. Seed size effects on yields of two corn hybrids. Journal of Production Agriculture, Madison, v.5, n.4, p.538-544, 1992.

NAKAJIMA, M. et al. Identiûcation and character ization of arabidopsis gibberellin receptors. Plant Journal, Oxford, v.46, p.880-889, 2006.

NATIONALCENTER FOR BIOTECHNOLOGY INFORMATION- NCBI, U.S. National Library of Medicine, USA, 2012. Available at: <http://www. ncbi.nlm.nih.gov> Accessed on: Oct 15, 2012. 
R DEVELOPMENT CORE TEAM. R: A language and environment for statistical computing. Vienna: $\mathrm{R}$ Foundation for Statistical Computing, 2008. Available at: <http://www.R-project.org>. Accessed on: Oct 22, 2011.

ROOD, S. B.; LARSEN, K. M. Gibberellins, amylase, and the onset of heterosis in maize seedlings. Journal of Experimental Botany, London, v.39, n.199, p.223-233, 1988.

SANA, N. K. et al. Enzyme activities and mobilization of nutrients in brassica (brassica spp.) and wheat (triticumaestivuml.) seeds during germination. Journal of Biosciences, Kamataka, v. 17, p.101-106, 2009.

SCHOLDBERG, T. A. et al. Evaluating precision and accuracy when quantifying different endogenous control reference genes in maize using real-time PCR.

Journal of Agricultural and Food Chemistry, Easton, v.57, p.2903-2911, 2009.

SONG, J. et al. Genome-wide identification of gibberellins metabolic enzyme genes and expression profiling analysis during seed germination in maize. Gene, Amsterdam, v.482, p.34-42, 2011.

SOPANEM, T.; LAURIÈRE, C. Release and activity of bound $\alpha$-amylase in a germinating barley grain. Plant Physiology, Minneapolis, v.89, p.244-249, 1989.
SOUZA, N. O. S. et al. Genetic control of traits associated with maize seed quality. Maydica, Bergamo, v.53, n.1, p.55-62, 2008.

TYAGI, S.; BRATU, D. P.; KRAMER, F. R. Multicolor molecular beacons for allele discrimination. Nature

Biotechnology, New York, v.16, n.1, p.49-53, 1998.

VIEIRA, R. D.; CARVALHO, N. M. Testes de vigor em sementes. Jaboticabal: FUNEP, 1994. p. 103-132.

VON PINHO, E. V. R. et al. Influência do tamanho e do tratamento de semente de milho na preservação da qualidade durante $\mathrm{o}$ armazenamento e posterior comportamento no campo. Ciência e Prática, Lavras, v.19, n.1, p.30-36, 1995.

YAMASAKI, Y. $\alpha$-amylase in germinating millet seeds. Phytochemistry, Nantes, v.64, p.935-939, 2003.

WANG, J. et al. Analysis of differential transcriptional proûling in wheat infected by Blumeria graminis f. sp. tritici using GeneChip. Molecular Biology Reports, Dordrecht, v.39, p.381-387, 2012.

XIE, Z. et al. Salicylic acid inhibits gibberellin-induced alpha-amylase expression and seed germination via a pathway involving an abscisic-acid-inducible WRKY gene. Plant Molecular Biology, Dordrecht, v.64, p.293303, 2007. 